УДК 656.225

\title{
ДОСЛІДЖЕННЯ ПРИЧИН ВИНИКНЕННЯ КОМЕРЦІЙНИХ НЕСПРАВНОСТЕЙ НА ЗАІЛЗНИЧНОМУ ТРАНСПОРТІ
}

Канд. техн. наук Д.І. Мкртичьян, В.О. Гаріфуллін, М.В. Литвишко ИССЛЕДОВАНИЙ ПРИЧИН ВОЗНИКНОВЕНИЯ КОММЕРЧЕСКИХ НЕИСПРАВНОСТЕЙ
НА ЖЕЛЕЗНОДОРОЖНОМ ТРАНСПОРТЕ

Канд. техн. наук Д.И. Мкртычьян, В.О. Гарифуллин, М.В. Литвишко

\section{RESEARCH THE REASONS EMERGENCE OF COMMERCIAL DISREPAIRS ON THE RAILVAY TRANSPORT}

Cand. of techn. sciences D.I. Mkrtychyan, V.O. Garifullin, M.V. Litvishko

У статті розглянуто причини виникнення комериійних несправностей, наслідки недотримання технічних умов навантаження $і$ кріплення вантажів та способи їх усунення.

Ключові слова: комериійні несправності, розвалення вантажу, технічні умови навантаження $i$ кріплення вантажів, пункт комериійного огляду.

В статье рассмотрены причины возникновения коммерческих неисправностей, последствия несоблюдения технических условий погрузки и крепления грузов и способы их устранения.

Ключевые слова: коммерческие неисправности, развал груза, технические условия погрузки и крепления грузов, пункт коммерческого осмотра.

A failure to observe of the Technical requirements of placing and fastening of loads in carriages results in a security of motion of trains breach and economies of loads, that is transported. Thus, a question of the reliable fastening and placing of loads in carriages is the important aspect of work of railway transport, in fact loading with violation of the set requirements creates a threat to safety of motion of trains, that in turn, negatively influences on quality of implementation of services in transportation of load and his safety. Violation of fastening and placing of load worsen the technological parameters of work of the station and, as a result, result in the origin of commercial disrepairs. Thus, a question, what amounts of commercial disrepairs related to reduction, is an actual task.

Keywords: commercial disrepairs, disintegration of load, technical requirements and fastening of loads, point of commercial examination.

Вступ i постановка проблеми у загальному вигляді та ії зв'язок із важливими науковими та практичними завданнями. Розвиток транспортної системи
України має бути орієнтований на забезпечення максимальної безпеки при перевезенні вантажів. Щодня до перевезень залізничним транспортом пред'являються вантажі, 
перевезення яких здійснюється у вагонах різного типу 3 різним кріпленням. Недотримання технічних умов розміщення i кріплення вантажів (ТУ) у вагонах призводить до порушення безпеки руху поїздів i збереження вантажів, які перевозяться. Таким чином, питання надійного кріплення i розміщення вантажів у вагонах $є$ важливим аспектом роботи залізничного транспорту, адже навантаження 3 порушенням встановлених вимог створює загрозу безпеці руху поїздів, що у свою чергу негативно впливає на якість виконання послуг з перевезення вантажу і його схоронність [6, 8]. Порушення кріплення i розміщення вантажу погіршують технологічні параметри роботи станції i, як наслідок, призводять до виникнення комерційних несправностей.

Визначення мети та задачі дослідження. Метою статті $€$ визначення причин виникнення комерційних несправностей і пропозиції щодо їх зменшення шляхом обов'язкового дотримання ТУ навантаження i кріплення вантажів i впровадження нових наукових досягнень для удосконалення технологій у сфері вантажної і комерційної роботи.

Аналіз останніх досліджень. Комерційні несправності, що виникають внаслідок порушення навантаження і кріплення вантажів, призводять до значних матеріальних втрат перевізника і вантажовласників. Вони пов'язані 3 додатковими простоями вагонів і витратами комерційних несправностей, додатковими витратами на їх виправлення i, як наслідок, порушеннями термінів доставки вантажів. Розвалення вантажу на шляху прямування може стати причиною виникнення великої аварії або катастрофи поїздів, що спричинить руйнування i знищення технічних споруд, травмування та загибель людей і забруднення навколишнього середовища $[1,2,9,4,3]$. Таким чином, питання, які пов'язані зі зменшенням кількості комерційних несправностей, $€$ актуальним завданням.

Основна частина дослідження. При розформуванні і формуванні вантажних поїздів через недосконалість і відхилення від ТУ виникає комерційна несправність. Комерційна несправність - несправність, що загрожує безпеці руху поїздів або за наявності якої не забезпечується збереженість вантажу: пошкодження вагона або контейнера, пошкодження пломб (ЗПП) відправника або пломб (ЗПП) попутних станцій, а також наявність ознак псування або пошкодження вантажу на відкритому рухомому складі [8].

Основними причинами виникнення комерційних несправностей $\epsilon[8,7]$ :

1) за станом вагонів і розміщенням у них вантажів:

- не закриті на запори двері і люки критих вагонів, борти платформ, люки і торцеві двері піввагонів у навантаженому стані;

- вихід вантажу за лобовий брус більш ніж на 400 мм при перевезенні на одиночних платформах i в піввагонах без прикриття; лісових вантажів - на 500 мм і більше, а також наявність відстані між кінцями вантажів, закріплених на суміжних платформах зчепа менше 270 мм;

- несправність тари (упаковки) вантажу, навантаженого на відкритому рухомому складі;

- злам підкладок, прокладок, брусів, клинів, щитів огородження i стійок, неправильне установлення стійок у стояковому гнізді, перекіс і невідповідність їх за розмірами вимог ТУ навантаження і кріплення вантажів;

- ослаблення натягу розтяжок, обв'язки і стандартних металевих стяжок, що кріплять вантаж на вагонах;

- просідання (провалення) вантажу через порушення цілісності підлог вагонів;

- нерівномірне розміщення однорідного вантажу по площі підлоги платформ i піввагонів;

- висипання навалювальних і насипних вантажів через щілини в дверях, нещільно закриті люки піввагонів i цементовозів, осипання таких вантажів через борти платформ і піввагонів при навантаженні їх 3 «шапкою» та ін.;

- навалювання вантажів на двері критих вагонів і великотоннажних контейнерів, який виявляється візуально;

- порушення (проломлювання) стін i дахів кузовів критих та ізотермічних вагонів $\mathrm{i}$ контейнерів;

- незакріплені опущені борти завантажених платформ при навантаженні, передбаченому ТУ;

- відсутність коротких стійок для закріплення секцій дерев'яних бортів платформ, завантажених навалювальними вантажами;

- наявність залишків раніше використаного дроту на завантажених платформах і в 
піввагонах, що загрожують безпеці руху поїздів при їх прямуванні та особистої безпеки людей при огляді рухомих складів;

- розміщення вантажів у піввагонах у нахиленому положенні 3 опорою на стінки кузова піввагона;

2) при завантаженні вагонів лісовими вантажами:

- розташування підкладок від кінців штабеля на відстані менше $0,5-0,8$ м і стійок від кінця штабеля на відстані менше 250 мм;

- піднесення над стійками крайніх колод, укладених у першому ряду «шапки», по висоті більш ніж на $1 / 4$ їх діаметра;

3) при навантаженні у вагони металів i виробів з них:

- відсутність клинових металевих запорів у торцевих бортів платформ або коротких дерев'яних стійок (за винятком випадків, коли такі вантажі допускаються до перевезення 3 відкритими торцевими бортами);

- наявність торцевих дерев'яних огорож по висоті нижче висоти штабеля навантаженого у вагони вантажу;

- відсутність клинових металевих запорів бічних бортів і зтягуючого дроту між протилежними короткими дерев'яними стійками;

- порушення дротяної або стрічкової обв'язки пачок навантаженого металу;

- відсутність дротяної ув'язки бічних стійок і торцевих щитів при навантаженні труб на платформах;

- відсутність обрешітки над торцевими бортами платформ або стінками піввагонів при перевезенні металобрухту;

4) при завантаженні вагонів вантажами в ящиках, пакетах, контейнерах і автотехнікою:

- незакріплений від поздовжнього i поперечного зміщення вантажів у ящиковій упаковці розпірними і упорними брусками і дротовими розтяжками;

- відсутність упорних, розпірних брусків і дротяного кріплення вантажів циліндричної форми;

- незакріплені упорними брусками i дротовими розтяжками вантажі на колісному i гусеничному ходу, стріл і навісного робочого обладнання кранів і екскаваторів (ковшів, захватів і т. д.);

- відсутність у комплекті одного або декількох контейнерів масою брутто 3 або 5 т, навантажених на платформах, у піввагонахконтейнеровозах або піввагонах;
- зсув великотоннажних контейнерів при перевезенні на спеціалізованих платформах через злам нижніх фітингів контейнерів на упорні головки платформ;

- розвалення транспортного пакета вантажу, навантаженого на відкритому рухомому складі;

5) за пломбуванням i блокуванням вагонів:

- відсутність пломб на дверях платформ, у тому числі порожніх льодовиків і вагонів, прямуючих під обробку на дезпромстанціі по II и III категоріям; на дверях кабін автотракторної техніки;

- несправність пломб (зрізування, обрив пломбувального дроту, підв'язка пломб, слід повторного стиснення, неправильна навіска);

- можливість витягування болтів 3 гранованою головкою 3 дверних накладок i наявність тріщин на вушках дверних накладок;

- відсутність на дверних накладках вагонів i запірних пристроях контейнерів дротяних закруток або наявність таких закруток зі слідами їх повторного накладення;

- наявність петлі навішування пломби розміром більше 45 мм при пломбуванні дверей вагонів і більше 25 мм при пломбуванні дверей контейнерів;

- можливість вільного переміщення затисненої пломби по навісці і витягування вузла навіски з пломби;

- відсутність пломб на вентиляційних люках льодовиків або повітряних ковпачках та інші додаткові пристосування спеціальних цистерн;

- незрозумілі відтиски на пломбах, якщо за ними не можна встановити найменування станції;

- відсутність пломб на брезенті при навантаженні вантажів 3 укриттям при наявності відміток про таке перевезення в перевізних документах;

6) пов'язані 3 умовами перевезення вантажів:

- незабезпечення вентилювання вантажів при закритих бічних люках вагонів, а також наявність незакріплених люків, які мають відхилення від стіни критого вагона більш ніж на 100 мм;

- наявність незвичайного (гнилісного, тухлого) запаху, що свідчить про можливе псування перевезеного у вагоні вантажу; 
- зміщення навантажених на платформи або транспортери негабаритних (великовагових) вантажів відносно контрольних смуг.

Перелічені вище комерційні несправності призводять до розвалення вантажу на шляху прямування, падіння вантажу або його частини, a також зміщення, розворот, порушення кріплення вантажу та інші несправності, що може викликати вихід вантажу за встановлений габарит навантаження або габарит рухомого складу, що, як наслідок, призводить до великих економічних втрат як з боку залізниці, так і 3 боку вантажоодержувача.

Для забезпечення схоронності вантажів при перевезенні діють транспортні статути, кодекси, правила перевезень і договори [3].

Спочатку правильність навантаження контролює вантажовідправник. Вантажовласник, відправляючи вантаж, зобов'язаний вживати всі залежні від нього заходи, що забезпечують його схоронність під час перевезення. Дотримання встановленого порядку i відповідне оформлення видачіприймання вантажу має вирішальне значення для виявлення обставин, при яких виникли нестача, псування або пошкодження вантажу, тобто виникла комерційна несправність [6].

При надходженні вантажу на станцію його огляд здійснюється працівниками ПКО. Кожна зміна очолюється старшим приймальником поїздів, у підпорядкуванні якого знаходяться приймальники поїздів i робочі для усунення комерційних несправностей. Технологія роботи ПКО має забезпечувати якісний комерційний огляд усіх поїздів і вагонів за час, зазначений $\mathrm{y}$ технологічних процесах роботи ПКО. Розроблення технологічних процесів виконується відповідно до Типового технологічного процесу роботи ПКО $[5,10]$. Технологічний процес роботи ПКО повинен передбачати використання сучасних технічних засобів, які забезпечують виявлення комерційних несправностей, їх оформлення i обмін оперативною інформацією ПКО: електронні габаритні ворота, електронні вагонні ваги, система телевізійного відеоконтролю, промислове телебачення, електронно-тензометричні ваги. Ці пристрої повинні забезпечувати передачу інформації 3 пристроїв на термінал оператора ПКО про наявність i розташування в поїзді вагонів 3 несправностями, порушення габариту навантаження, ТУ розміщення та кріплення вантажів на відкритому рухомому складі, перевантаження вагонів $[6,7]$.

Висновки $з$ дослідження і перспективи, подальший розвиток у даному напрямку. Для запобігання, а за необхідності усунення комерційних несправностей, а також зведення ïх до мінімуму необхідно суворе дотримання ТУ на всьому шляху прямування. На основі вищевикладеного можна зробити висновок, що на всіх етапах розвитку залізничного транспорту вчені i працівники залізниць приділяють значну увагу питанню комерційних несправностей через порушення i кріплення вантажу, але в сучасних умовах розвитку інформаційних систем виникає необхідність перегляду деяких можливостей і положень, що стосуються виникнення комерційних несправностей. Обов'язковою умовою для скорочення комерційних несправностей $\epsilon$ технічне переозброєння рухомого складу залізничного транспорту, постійне підвищення кваліфікації працівників ПКО, поповнення сучасної апаратури діагностики та обслуговування вагонів і вантажів, а також постійне вдосконалення i розвиток різних методів розрахунку i способів кріплення i розміщення вантажів.

\section{Список використаних джерел}

1. Запара, В.М. Аналіз роботи пунктів комерційного огляду на станції Красний Лиман Донецької залізниці [Текст] / В.М. Запара, Я.В. Запара, К.С. Акулініна // Зб. наук. праць. - Харків: УкрДАЗТ, 2012. - Вип. 128. - С. 17-21.

2. Запара, В.М. Дослідження роботи пунктів комерційного огляду станції ДебальцевеСортувальна Донецької залізниці [Текст] / В.М. Запара // Зб. наук. праць. - Харків: УкрДАЗТ, 2013. Вип. 137. - С. 40-46.

3. Кузнецов, М.М. Забезпечення безпеки руху і схоронності вантажів на залізницях [Текст] / М.М. Кузнецов // Залізничний транспорт України. - 2005. - № 3/1. - С. 19. 
4. Ломотько, Д.В. Підвищення рівня схоронності вантажів, що перевозять по залізницях України [Текст] / Д.В. Ломотько, М.М. Кузнецов, О.М. Пилипейко // Наука в транспортном измерении. - К.: ДНДЦ УЗ, 2006. - С. 67.

5. ПКО у забезпеченні безпеки руху [Електронний ресурс]. - Режим доступу: http//www.uz.gov.ua.

6. Посібник прийомоздавальника вантажу та багажу (ЦМ-0016) [Текст]: нормативно-технічне видання; наказ Укрзалізниці № 388-Ц від 31.07.2007 р. - К. : Укрзалізниця, 2008. -224 с.

7. Правила комерційного огляду поїздів та вагонів [Текст]: нормативно-технічне видання; наказ Укрзалізниці № 152-Ц від 26.04.2006 р. - К.: ТОВ “Швидкий рух”, 2006. -32 с.

8. Правила размещения и крепления грузов в вагонах и контейнерах (Приложение 14 к СМГС) на 1.07.2014 г. [Электронный ресурс]. - Режим доступа: http//www.uz.gov.ua.

9. Смехов, А.А. Грузоведение, сохранность и крепление міхов [Текст] / А.А. Смехов, А.Д. Малов, А.М. м міхова кий [и мі.]; под. міх. А.А. міхова. - М.: Транспорт, 1987. - 239 с.

10. Типовий технологічний процес роботи пункту комерційного огляду поїздів (ПКО) [Текст]: нормативно-технічне видання; наказ Укрзалізниці № 178-Ц від 28.03.2007 р. - К.:ТОВ “ВД "Мануфактура", 2007. - 28 с.

\section{Рецензент д-р техн. наук, професор С.С. Альошинський}

Мкртичьян Дмитро Ігорович, канд. техн. наук, доцент кафедри управління вантажною і комерційною роботою, Українська державна академія залізничного транспорту. Тел.: 057-730-10-11.

Гаріфуллін Віталій Олегович, слухач групи МЗ-ОПУТ-Б12-ТЕД.

Литвишко Маргарита Валеріївна, студент групи 13-VI-ОПУТм.

Mkrtychyan Dmitry Igorovich, Cand. of techn. sciences, associate professor of the chair "Management of freight and commercial operation". Tel.: 057-730-10-11.

Garifullin Vitaliy Olegovich, student of the group M3-ROM-B12-TEW.

Margarita Valeriyvna Lintvishko, student of the group 13- VI-ROMм. 